\title{
ANALISIS GERAK DASAR FUNDAMENTAL PADA SISWA KELAS ATAS SEKOLAH DASAR NEGERI 2 CIHERANG JAYA KECAMATAN CISATA
}

\author{
Rusmiyadi ${ }^{1}$, Syukron Ma'mun², Asroriyah ${ }^{3}$ \\ STKIP Syekh Manshur ${ }^{1,2,3}$ \\ yadirusmi2@gmail.com
}

\begin{abstract}
ABSTRAK
Perkembangan gerak dimasa anak-anak sangat menonjol,terutama pada kemampuan gerak lokomotor, nonlokomotor dan manipulatif. Penyempurnaan atau perbaikan gerak dasar terjadi pada masa anak-anak. Menjelang masa remaja gerak yang makin kompleks bisa dikuasai dengan kemampuan memanfaatkan keterampilan gerak sesuai dengan kebutuhannya. Pada akhirnya masa awal dewasa berbagai organ tubuh mencapai puncak perkembangan fungsi, dan fisik mencapai puncak kematangannya. Gerak merupakan kebutuhan utama bagi manusia, sebagian besar kebutuhan manusia dapat tercapai melalui gerak. Kemampuan gerak pada anak sebaiknya dilakukan pada usia sedini mungkin, agar perkembangan dan pertumbuhan dapat terpantau dengan baik dan benar. Selain itu, perkembangan gerak pada anak juga merupakan salah satu faktor yang sangat penting bagi perkembangan individual secara keseluruhan. Pendekatan yang dilakukan dalam penelitian ini adalah penelitian kualitatif dengan metode pengumpulan data yang digunakan adalah metode dokumentasi, metode observasi metode tes terhadap semua yang terjadi dalam gerak dasar fundamental. Metode dokumentasi bertujuan untuk memperoleh data peserta (subyek penelitian) yang sesuai dengan klasifikasi yang ada disekolah dasar. Metode observasi digunakan untuk mengetahui kondisi yang bersifat objektif atau yang benar terjadi dilapangan. Sedangkan metode tes digunakan untuk mengatahui kemampuan gerak dasar fundamental siswa kelas atas sekolah dasar.
\end{abstract}

Kata Kunci: Gerak; Fundamental; Siswa Kelas Atas;

\begin{abstract}
Movement development in childhood is very prominent, especially in the ability to move locomotor, nonlocomotor and manipulative. Completion or improvement of basic movements occurs in childhood. Towards adolescence, increasingly complex movements can be mastered with the ability to utilize movement skills according to their needs. At the end of early adulthood, various organs of the body reach the peak of functional development, and the physical reaches its peak of maturity. Motion is the main need for humans, most human needs can be achieved through motion. Movement ability in children should be done at the earliest possible age, so that development and growth can be monitored properly and correctly. In addition, the development of movement in children is also a very important factor for the development of the individual as a whole. The approach taken in this research is qualitative research with data collection methods used are documentation methods, observation methods, test methods for everything that occurs in the fundamental movements. The documentation method aims to obtain participant data (research subjects) in accordance with the existing classifications in elementary schools. The observation method is used to determine the conditions that are objective or true in the field. While the test method is used to determine the fundamental basic movement abilities of upper grade elementary school students.
\end{abstract}

Key Words: words; key; maximal; 5 words

Dipublikasikan Oleh :

UPT Publikasi dan Pengelolaan Jurnal

Universitas Islam Kalimantan Muhammad Arsyad Al-Banjari Banjarmasin 


\section{PENDAHULUAN}

Pendidikan jasmani dan olahraga di sekolah dasar pada hakikatnya mempunyai arti peran dan fungsi yang amat vital dan strategis dalam upaya menciptakan suatu masyarakat yang sehat dan dinamis. Pendidikan jasmani dan olahraga merupakan sebuah wadah yang mendorong peserta didik untuk mengembangkan keterampilan motorik, kemampuan fisik, pengetahuan, penalaran, dan membiasakan pola hidup sehat yang bertujuan utnuk merangsang pertumbuhan dan perkembangan yang seimbang. Dalam ranah pendidikan, aktivitas jasmani merupakan kegiatan peserta didik dalam meningkatkan keterampilan motoriknya dan nilai-nilai fungsional yang mencakup ranah kognitif, afektif, dan psikomotor, sehingga pendidikan jasmani diharapkan dapat mengoptimalkan tumbuh kembang sehat jasmani dan rohani pada peserta didik.

Gerak dasar merupakan kemampuan yang pasti akan dikuasai oleh setiap orang, oleh karenanya perlu untuk memantau penguasaan gerak dasar bagi siswa. Karena pada setiap tahap berbeda pula kriteria penguasaan geraknya baik itu pada anak-anak, remaja, maupun dewasa. Penguasaan gerak pada level anak-anak penting dilakukan karena dengan seorang anak menguasai berbagai keterampilan gerak niscaya dia akan semakin terlibat aktif dalam kegiatan yang bersifat gaya hidup aktif. Terlibat dalam aktifitas fisik secara langsung dapat mencegah obesitas, selain itu juga dapat mengembangkan kemampuan kognititf (Ricarhd, 2012).

A. Gerak Dasar Fundamental

Gerak dasar fundamental adalah gerakan-gerakan dasar yang berkembangnya terjadi sejalan dengan pertumbuhan tubuh dan tingkat kematangan pada anak-anak, gerakan dasar fundamental mulai bisa dilakukan oleh seseorang sebagian pada masa bayi dan sebagian pada masa anak-anak, gerakan dasar di sempurnakan pada masa sesudahnya melalui proses latihan atau melakukan berulang-ulang. Gerakan dasar fundamental dapat di bagi menjadi tiga:

\section{Gerak Lokomotor}

Gerak Lokomotor adalah Gerak gerakan berpindah tempat, dimana bagian tubuh tertentu bergerak atau berpindah tempat. Gerak lokomotor adalah gerak memindahkan tubuh dari satu tempat ketempat yang lain. Gerak dasar lokomotor merupakan salah satu domain dari gerak dasar fundamental, keterampilan lokomotor didefinisikan sebagai keterampilan berpindahnya individu dari satu tempat ke tempat yang lain, (Hidayat, 2017). Sebagian besar keterampilan lokomotor berkembang dari hasil dari tingkat kematangan tertentu, namun latihan dan pengalaman juga penting untuk mencapai kecakapan yang matang. Keterampilan lokomotor misalnya berlari cepat, mencongklang, meluncur, dan melompat lebih sulit dilakukan karena merupakan kombinasi dari pola-pola gerak dasar yang lain.

Keterampilan lokomotor membentuk dasar atau landasan koordinasi gerak kasar dan melibatkan gerak otot besar. Gerakan-gerakan lokomotor adalah gerakan-gerakan yang pergi ke mana saja. Para ahli mendefinisikan gerakan lokomotor sebagai gerakan-gerakan yang menyebabkan tubuh berpindah tempat atau mengembara dalam berbagai ruang, sehingga dalam bahasa Inggris disebut juga traveling. Ini tentunya merupakan kebalikan dari gerakan nonlokomotor, yang tidak menyebabkan tubuh berpindah dari satu tempat ke tempat lain. Gerakan lokomotor merupakan dasar bagi perkembangan koordinasi gerakan yang melibatkan otototot besar, pertumbuhan otot, daya tahan dan stamina. Gerak lokomotor adalah gerak memindahkan tubuh dari satu tempat ke tempat yang lain. Macam-macam gerak lokomotor, yaitu : lari, lompat, loncat, leaping, jingkat, menderap, sliding, skiping,rolling,dan memanjat.

a. Berjalan

Berjalan adalah aktivitas gerak memindahkan tubuh dari satu tempat ke tempat yang lain, pada saat kaki melakukan pergantian langkah salah satu kaki tetap menumpu pada dasar pijakan. Dengan konsep di atas, berjalan dapat dilakukan dengan kaki, dengan tangan, dengan kaki dan tangan, dengan tubuh; demikian juga arahnya, ke depan dan ke belakang, ke samping kiri dan kanan, dalam hal usaha, bisa cepat, lambat, keras, perlahan, terhenti-henti, berkelanjutan; dalam hal keterhubungan, bisa di sekitar ruangan, di sekitar teman sendiri, melintasi atau melangkahi alat.

b. Berlari

Berlari adalah aktivitas gerak memindahkan tubuh dari satu tempat ke tempat yang lain, pada saat kaki melakukan pergantian langkah badan dalam keadaan melayang di udara. Aplikasikan konsep-konsep di atas, sesuai dengan tema berlari.

c. Berjingkat

Berjingkat adalah aktivitas memindahkan tubuh dari satu tempat ke tempat yang lain dengan menggunakan satu kaki, menumpu dan mendarat menggunakan satu kaki, sedangkan satu kaki yang lain ditekuk pada bagian lutut sehingga tidak menyentuh tanah. Keterampilan berjingkat selain sering digunakan dalam

Dipublikasikan Oleh :

UPT Publikasi dan Pengelolaan Jurnal

Universitas Islam Kalimantan Muhammad Arsyad Al-Banjari Banjarmasin 
kehidupan sehari-hari juga sering digunakan dalam aktivitas motorik pada beberapa cabang olahraga seperti lompat jangkit, sepak bola, bola voli dan bola basket.

d. Meloncat

Meloncat adalah gerakan memindahkan tubuh dengan menggunakan dua atau satu kaki tumpu dari satu ketinggian dan mendarat tidak harus menggunakan kaki.

e. Menderap

Menderap atau mencongkang adalah gerakan berjalan dipadukan dengan lompat (leaping), arah dapat ke depan maupun ke belakang. Gerakan ini seperti kuda pada saat berlari kencang (menderap), tetapi hanya dilakukan dengan menggunakan dua kaki.

f. Merayap

Merayap adalah gerakan yang dilakukan dengan posisi tubuh telungkup di atas permukaan, tangan dan kaki kiri atau kanan digerakkan maju secara bersama-sama, kemudian kaki mendorong tubuh ke depan, dan kepala sedikit diangkat untuk melihat ke depan.

g. Memanjat

Memanjat adalah gerakan ke atas atau ke bawah dengan menggunakan kedua tangan dan kaki. Biasanya anggota tubuh bagian atas sebagai alat kontrol utama agar tidak jatuh.

\section{Gerak Nonlokomotor}

Gerakan nonlokomotor dapat diartikan juga sebagai keterampilan stabil, gerakan yang dilakukan tanpa atau hanya sedikit sekali bergerak dari daerah tumpuannya. Gerakan nonlokomotor adalah gerakan yang dilakukan ditempat (Hidayat, 2017). Dapat juga didefinisikan sebagai gerakan-gerakan yang dilakukan dengan gerakan yang memerlukan dasar-dasar penyangga yang minimal atau tidak memerlukan penyangga sama sekali atau gerak tidak berpindah tempat. Gerakan non lokomotor adalah aktivitas yang menggerakkan anggota tubuh pada porosnya dan pelaku tidak pindah tempat. Bentuk-bentuk gerak nonlokomotor, yaitu menghindar, meregangkan otot, memutar dan berputar, mengayunkan kaki, bergantung, menarik, dan yang terakhir adalah mendorong.

3. Gerak Manipulatif

Gerak Manipulatif melibatkan tindakan mengontrol suatu objek khususnya dengan tangan dan kaki. Gerak manipulatif adalah gerak yang memberi atau menerima sebuah objek atau benda tertentu (Kurniawan, 2018) sedangkan menurut (Komari, 2014) gerak dasar manipulatif merupakan gerak dasar menggunakan organ tubuh untuk dapat memanipulasi benda, benda yang dimanipulasi dapat berupa ditendang, dilempar dan ditangkap dan beberapa jenis lain seperti memukul dalam permainan bolavoli, badminton ataupun tenis lapangan . Ada dua klasifikasi keterampilan dari gerak manipulatif, yaitu reseptif dan propulsif. Keterampilan reseptif adalah menerima suatu objek seperti menangkap dan keterampilan propulsif memiliki ciri pengerahan gaya atau kekuatan terhadap suatu objek, seperti memukul, melempar, memantul atau menendang. Gerakan manipulatif adalah keterampilan motorik yang melibatkan penguasaan terhadap objek di luar tubuh oleh tubuh atau bagian tubuh.

Memukul adalah suatu aksi menggunakan satu atau dua tangan atau suatu alat untuk mendorong (memberikan daya pada) suatu obyek. Anak-anak kelas satu dan dua masih sulit memukul benda bergerak, dan memukul menggunakan tongkat yang bulat, karena kesadaran visualnya masih rendah. Untuk melatih keterampilan memukul sebaiknya menggunakan alat pemukul yang pipih dengan permukaan untuk memukul lebar, sedangkan bola yang digunakan sebaiknya bola yang ringan.

B. Perkembangan Gerak

Perkembangan motorik pada manusia diawali dengan fase gerak refleks (reflexive movement phase) yang terjadi pada bayi dalam kandungan hingga berumur 1 tahun dan diakhiri dengan fase gerak khusus (specialized movement phase) yang terjadi pada umur 14 ke atas. Fase selanjutnya adalah fundamental movement abilities atau kemampuan gerak dasar dimana anak secara aktif belajar dan melatih kemampuan gerak dari tubuh mereka Pada fase inilah mereka kemudian mempelajari bagaimana melakukan berbagai gerakan lokomotor, nonlokomotor dan manipulatif secara terpisah dan berkesinambungan. Kemampuan gerak dasar pada anak berperan aktif terhadap perkembangan fisik, sosial dan kesehatan emosional baik dalam jangka pendek maupun jangka panjang (Hands, 2012). Perkembangan motorik anak terbagi menjadi dua bagian, yaitu gerak motorik kasar dan gerak motorik halus. Kemampuan motorik kasar seseorang berbeda-beda tergantung dengan banyaknya pengalaman gerak yang mereka lakukan. Perkembangan motorik merupakan salah satu aspek pertumbuhan anak-anak yang begitu jelas terlihat. Sanders dalam (Beaty, 2013) mengemukakan bahwa "kami memahami bahwa perkembangan fisik seorang anak bergantung pada biologinya tetapi kita juga perlu mempertimbangkan pendapat Vygotsky bahwa kondisi lingkungan sama pentingnya”. Menurut (Nur, Mulyana,

Dipublikasikan Oleh :

UPT Publikasi dan Pengelolaan Jurnal

Universitas Islam Kalimantan Muhammad Arsyad Al-Banjari Banjarmasin 
\& Perdana, 2017) Perkembangan motorik kasar berupa koordinasi gerakan tubuh seperti berlari, berjinjit, melompat, bergantung, melempar, menangkap dan sebagainya. Kegiatan tersebut diperlukan untuk meningkatkan kemampuan koordinasi gerakan motorik kasar.

Menurut Hadis dalam (Yasbiati, dan Nur, 2017) untuk merangsang motorik kasar anak dapat dilakukan dengan melatih anak untuk meloncat, memanjat, memeras, bersiul, membuat ekspresi muka senang, sedih, gembira, berlari, berjinjit, berdiri diatas satu kaki, berjalan dititian dan sebagainya. Jadi dapat disimpulkan bahwa gerak motorik kasar adalah kemampuan yang membutuhkan koordinasi sebagian besar tubuh anak dan biasanya memerlukan tenaga karena dilakukan oleh otot-otot besar. Pengembangan gerak motorik kasar juga memerlukan koordinasi kelompok otot-otot tertentu yang dapat membuat mereka dapat meloncat, memanjat, berlari, berjalan, berjinjit, berdiri diatas satu kaki, dan lain-lain.

Perkembangan fisik motorik memiliki peranan sama penting dengan aspek perkembangan yang lain, perkembangan motorik dapat dijadikan sebagai tolak ukur pertama untuk mengetahui tumbuh kembang anak. Hal ini disebabkan perkembangan fisik motorik dapat diamati dengan mudah melalui panca indera, seperti perubahan ukuran pada tubuh anak. Menurut (Papalia, 2014) pertumbuhan dan perkembangan fisik mengikuti prinsip sefalokaudal dan proximodistal. Menurut prinsip sefalokaudal, pertumbuhan terjadi dari atas ke bawah, karena otak tumbuh dengan cepat sebelum lahir, kepala bayi yang baru lahir adalah disproporsi besar. Menurut prinsip proximodistal pertumbuhan dan perkembangan motorik dari dalam ke luar (pusat tubuh ke luar), dalam rahim kepala dan badan berkembang sebelum lengan dan kaki, kemudian tangan dan kaki, dan jari tangan dan kaki. Anggota badan terus tumbuh lebih cepat daripada tangan dan kaki pada anak usia dini.

Perkembangan fisik adalah pertumbuhan dan perubahan yang terjadi pada tubuh seseorang. Perubahan yang paling jelas terlihat adalah perubahan pada bentuk dan ukuran tubuh seseorang. Perkembangan motorik (motor development) adalah perubahan yang terjadi secara progressif pada kontrol dan kemampuan untuk melakukan gerakan yang diperoleh melalui interaksi antara faktor kematangan (maturation) dan latihan atau pengalaman (experiences) selama kehidupan yang dapat dilihat melalui perubahan/pergerakan yang dilakukan. (Rini Hildayani, 2016). Sebelum perkembangan terjadi anak tidak akan berdaya. Kondisi tersebut akan berubah secara cepat pada usia 4-5 tahun pertama kehidupan pasca lahir. Anak dapat mengendalikan gerakan yang kasar. Gerakan tersebut melibatkan anggota badan yang luas yang digunakan untuk berjalan, melompat, berlari, berjinjit, berenang, dan sebagainya. Setelah berumur 5 tahun terjadi perkembangan yang besar dalam pengendalian koordinasi yang lebih baik yang melibatkan bagian otot yang lebih kecil yang digunakan untuk menggenggam, melempar, menangkap bola, menulis, dan sebagainya. Salah satu perbedaan mencolok antara anak usia dini dengan bayi dan balita adalah anak prasekolah tidak memiliki lemak bayi dan tampak lebih ramping.

Perampingan ini dan meningkatknya koordinasi gerak memudahkan anak usia dini untuk lebih percaya diri berpartisipasi dalam aktivitas perpindahan yang sangat penting dalam tahap pertumbuhan dan perkembangan motoriknya. Perkembangan fisik motorik anak ditandai dengan pertumbuhan fisik yang meliputi peningkatan berat badan, tinggi badan, lingkar kepala, dan tonus otot. Kurang optimalnya pertumbuhan fisik anak dapat menjadi pertanda ada sesuatu yang terjadi dalam diri anak. Pada usia tiga tahun, tubuh, tangan, dan kaki anak akan tumbuh semakin panjang. Kepala masih relatif besar, tubuh bagian lainnya berusaha menyusul seiring dengan semakin miripnya bagian anggota tubuh anak dengan tubuh orang dewasa (Morrison, 2012).

Perkembangan motorik meliputi perkembangan motorik kasar dan motorik halus. Motorik kasar melibatkan otot-otot besar dan motorik halus melibatkan otot-otot kecil. Gerakan-gerakan yang dilakukan oleh anak melibatkan otot dan anak pada masa tataran usia dini lebih cenderung aktif/lebih senang bergerak, lebih senang melakukan percobaan atau praktik, lebih senang bermain baik permainan yang membutuhan banyak energi maupun permainan yang hanya menampakkan sedikit gerakan. Sedikit ataupun banyak gerakan yang dilakukan tetap melibatkan otot, sehingga perkembangan motorik sangat menunjang aspek perkembangan yang lain. Seperti yang dipaparkan oleh (Sher, 2009) gross motor activities requiring coordination, such as various types of sports, or even tasks, such as jumping forward. Motorik kasar merupakan aktivitas fisik yang memerlukan koordinasi seperti berbagai jenis olah raga atau tugas-tugas sederhana seperti gerakan melompat. Diperjelas oleh (Decaprio, 2013) motorik kasar merupakan gerakan tubuh dengan menggunakan otot-otot besar ataupun sebagian besar otot yang ada dalam tubuh maupun seluruh anggota tubuh yang dipengaruhi oleh kematangan diri.

Melalui gerakan-gerakan tersebut dan kesempatan yang diberikan oleh guru maupun orang tua menjadikan gerakan-gerakan tersebut sebagai stimulasi perkembangan motorik anak usia dini baik motorik kasar maupun motorik halus. Saat bermain anak berlatih menyesuaikan antara pikiran dan gerakan menjadi suatu keseimbangan, anak terlahir dengan kemampuan refleks, dan belajar menggabungkan dua atau lebih gerak refleks, sehingga anak mampu mengontrol gerakannya dan menjadi gerak terkoordinasi. (Khasanah, Prasetyo, \&

Dipublikasikan Oleh :

UPT Publikasi dan Pengelolaan Jurnal

Universitas Islam Kalimantan Muhammad Arsyad Al-Banjari Banjarmasin 
Rakhmawati, 2011) menyatakan ada beberapa prinsip permainan yaitu permainan adalah sesuatu yang menyenangkan, permainan adalah wadah bereksprimen dalam berbagai hal, permainan adalah sesuatu yang aktif dan dinamis tidak dibatasi oleh ruang dan waktu. Permainan berlaku bagi setiap anak di sepanjang zaman, memiliki konteks hubungan sosial dan spontan, sebagai sarana komunikasi antar anak dan lingkungan.

Menurut (Santrock, 2011) keterampilan motorik kasar anak pada usia 3 tahun menikmati gerakan-gerakan sederhana, seperti meloncat, melompat, dan beralari bolak balik yang dilakukan oleh anak hanya karena senang melakukan aktivitas tersebut. Anak merasa cukup bangga menunjukkan kemampuannya dalam berlari dan melompat. Usia 4 tahun, anak masih menikmati jenis aktivitas yang sama, tetapi menjadi lebih senang berpetualang, anak dapat merangkak rendah, menaiki tangga dan turun dengan cara yang sama yaitu anak masih sering kembali menjejakkan kaki pada setiap anak tangga. Anak berusia 5 tahun senang berpetualang dan dapat berlari cepat satu sama lain. Sedangkan pada keterampilan motorik halus anak pada usia 3 tahun anak menunujukkan kemampuan yang lebih matang untuk mencari dan menangani sesuatu dibandingkan ketika anak masih bayi. Meskipun untuk beberapa waktu anak mampu memungut objek terkecil dengan ibu jari dan jari telunjuk, anak masih canggung dengan hal tersebut. Anak juga dapat membangun sebuah menara balok yang sangat tinggi, tetapi tidak sepenuhnya dalam garis lurus. Ketika bermain puzzle anak agak kasar menempatkan potongan-potongan puzzle, bahkan ketika mengenali lokasi yang cocok, penempatan potongan puzzle belum begitu tepat. Anak sering mencoba memaksakan potongan tersebut pada tempatnya atau menepuknya dengan keras.

\section{METODE}

Variabel penelitian yang dianalisis adalah gerak dasar fundamental siswa kelas atas sekolah dasar. Teknik pengumpulan data merupakan utama dalam penelitian karena tujuan utama dari penelitian adalah mendapatkan data, (Arikunto, 2010).

Penelitian melakukan pengumpulan data dengan cara triangulasi, peneliti mengumpulkan data bersamaan dengan menguji kredibilitas data ayang diperoleh, yaitu mengecek kredibilitas data dengan berbagai teknik pengumpulan data dan berbagai sumber data .

Penelitian melakukan pengumpulan data dengan cara triangulasi, peneliti mengumpulkan data bersamaan dengan menguji kredibilitas data ayang diperoleh, yaitu mengecek kredibilitas data dengan berbagai teknik pengumpulan data dan berbagai sumber data, (Sugiyono, 2013).

Analisis data kualitatif yaitu reduksi data, penyajian data dan verifikasi data atau penarikan kesimpulan (Sugiyono, 2013).. Kesimpulan yang diberika sesuai denga hasil yang diperoleh dari analisis data.

Alur penelitian dapat digambarkan sebagai berikut:

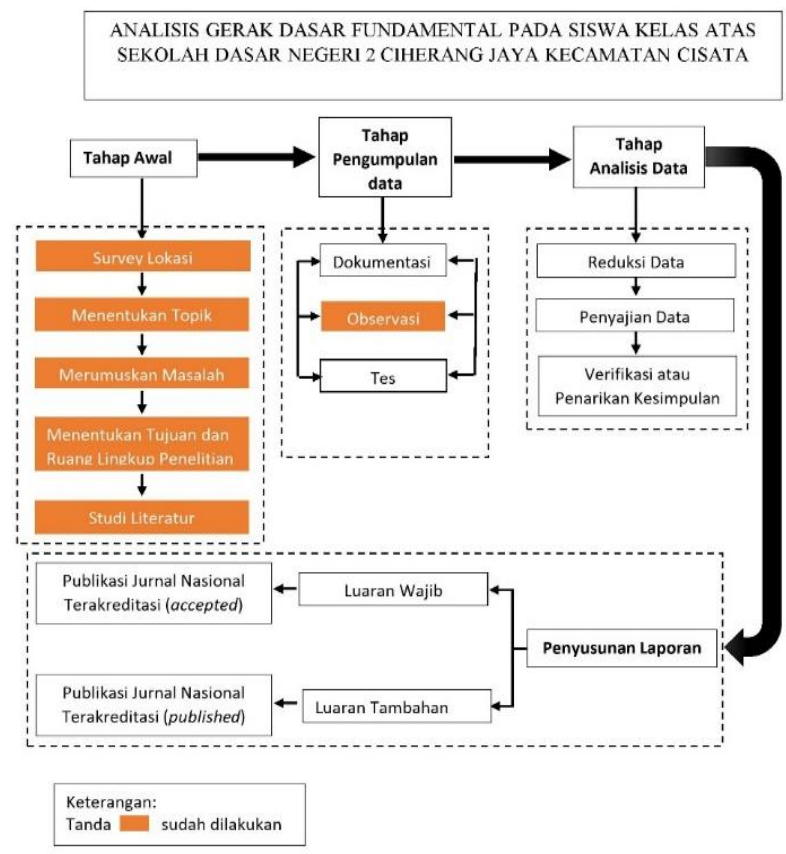

Gambar 1 Alur Penelitian

Dipublikasikan Oleh :

UPT Publikasi dan Pengelolaan Jurnal

Universitas Islam Kalimantan Muhammad Arsyad Al-Banjari Banjarmasin 


\section{HASIL DAN PEMBAHASAN}

Analisa hasil penelitian dilakukan untuk menjawab tujuan penelitian yaitu melihat perkembangan keterampilan gerak dasar siswa kelas atas. Deskripsi data yang disajikan berupa deskripsi data dari masingmasing gerakan dasar yang dikelompokkan menjadi gerak dasar fundamental lokomotor, gerak dasar fundamental non lokomotor dan gerak dasar fundamental manipulatif.

Tabel. 1 Deskripsi Data Hasil Gerak Dasar Fundamental Siswa

\begin{tabular}{|c|c|c|c|c|c|c|c|c|}
\hline \multicolumn{2}{|l|}{ Skill } & \multicolumn{2}{|c|}{$\begin{array}{c}\text { Skor } \\
\text { Maksimal }\end{array}$} & \multicolumn{2}{|c|}{$\begin{array}{c}\text { Skor Rata- } \\
\text { rata }\end{array}$} & \multicolumn{3}{|c|}{ Kriteria \% } \\
\hline & \multirow{7}{*}{ 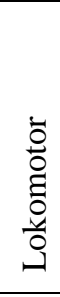 } & $\mathrm{L}$ & $\mathrm{P}$ & $\mathrm{L}$ & $\mathrm{P}$ & Baik & Sedang & Kurang \\
\hline Lari & & 25 & 28 & 3.1 & 4 & 75 & 20.8 & 4.2 \\
\hline Galop & & 25 & 27 & 3.1 & 3.8 & 50 & 41.7 & 8.3 \\
\hline Leap & & 23 & 26 & 4.6 & 3.7 & 20.8 & 66.7 & 12.5 \\
\hline Lompat & & 27 & 29 & 3.4 & 4.1 & 70.8 & 20.9 & 8.3 \\
\hline Meloncat horizontal & & 26 & 29 & 3.2 & 4.1 & 58.3 & 29.2 & 12.5 \\
\hline Maluncur & & 24 & 28 & 3 & 4 & 41.6 & 54.2 & 4.2 \\
\hline Mendorong & \multirow{3}{*}{ 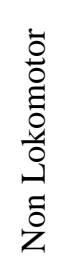 } & 30 & 35 & 3.7 & 5 & 70.8 & 29.2 & 0 \\
\hline Menarik & & 28 & 28 & 3.5 & 4 & 54.2 & 41.6 & 4.2 \\
\hline Memilin Badan & & 29 & 31 & 3.6 & 4.1 & 66.7 & 25 & 8.3 \\
\hline Memukul bola diam & \multirow{6}{*}{ 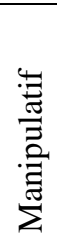 } & 28 & 30 & 3.5 & 4.3 & 54.2 & 41.6 & 4.2 \\
\hline Dribble diam & & 26 & 29 & 3.2 & 4.1 & 8.3 & 79.2 & 12.5 \\
\hline Menangkap & & 25 & 28 & 3.1 & 4 & 33.3 & 62.5 & 4.2 \\
\hline Menendang & & 23 & 27 & 4.6 & 3.8 & 12.5 & 83.3 & 4.2 \\
\hline Melempar atas & & 24 & 28 & 3 & 4 & 25 & 70.8 & 4.2 \\
\hline Menggelinding bola & & 27 & 28 & 3.4 & 4 & 38.3 & 29.2 & 12.5 \\
\hline
\end{tabular}

Pada kategori gerak lokomotor, gerakan lari adalah gerakan yang paling baik dikuasai oleh siswa. Hal ini didasarkan pada angka persentase sebesar 75\%. Selanjutnya diikuti gerakan lompat pada kisaran angka $70.8 \%$. Sedangkan pada kaegori gerak dasar non lokomotor yang kurang dikuasi oleh siswa memilin badan pada angka $8.3 \%$ Untuk kategori gerak dasar fundamental yang dikuasai oleh siswa Memukul bola diam dengan angka $54.2 \%$.

\section{PENUTUP}

Sesuai dengan pembahasan yang telah diuraikan sebelumnya, ada beberapa hal yang dapat disimpulkan yaitu kondisi perkembangan gerak dasar siswa kelas atas belum begitu baik. Hal ini dibuktikan dengan hasil analisis gerak dasar yang menyatakan keseluruhan siswa memiliki gerak dasar fundamental lokomotor dan gerak dasar fundamental manipulatif yang berada pada kategori kurang.

\section{REFERENSI}

Arikunto, S. (2010). Prosedur Penelitian Suatu Pendekatan Praktik. (R. Cipta, Ed.). Jakarta: PT Bumi Timur Jaya.

Beaty, J. J. (2013). Observasi Perkembangan Anak Usia Dini. (Kenca, Ed.). Jakarta: PT Bumi Timur Jaya. Decaprio, R. (2013). Aplikasi Teori Pembelajaran Motorik di Sekolah. (DIVA Press, Ed.). Yogyakarta. Hands, B. P. (2012). How fundamental are fundamental movement skills? Active and Healthy Magazine, 19(1). Hidayat, A. (2017). Peningkatan aktivitas gerak lokomotor, nonlokomotor dan manipulatif menggunakan model

Dipublikasikan Oleh :

UPT Publikasi dan Pengelolaan Jurnal

Universitas Islam Kalimantan Muhammad Arsyad Al-Banjari Banjarmasin 
permainan pada siswa sekolah dasar. Jurnal Pendidikan Jasmani Dan Olahraga, 2(2), 21-29.

Khasanah, I., Prasetyo, A., \& Rakhmawati, E. (2011). Permainan tradisional sebagai media stimulasi aspek perkembangan anak usia dini. PAUDIA: Jurnal Penelitian Dalam Bidang Pendidikan Anak Usia Dini, $1(1)$.

Komari, A. (2014). Kemampuan Gerak Manipulatif Mahasiswa Peserta Perkuliahan Permainan Net Tahun Angkatan 2010. Jurnal Pendidikan Jasmani Indonesia, 10(1).

Kurniawan, R. (2018). ANALISIS GERAK DASAR ANAK USIA 6-7 TAHUN. JPUD - Jurnal Pendidikan Usia Dini. https://doi.org/10.21009/jpud.122.12

Morrison, G. S. (2012). Dasar-Dasar Pendidikan Anak Usia Dini. (Indeks, Ed.). Jakarta: PT Bumi Timur Jaya.

Nur, L., Mulyana, E. H., \& Perdana, M. A. (2017). Permainan Bola Kecil Untuk Meningkatkan Keterampilan Motorik Kasar Anak Usia Dini pada Kelompok B di TK Pertiwi DWP Kota Tasikmalaya. Jurnal PAUD Agapedia, 1(1), 53-65.

Papalia, D. E. (2014). Menyelami Perkembangan Manusia. (Salemba Humanika, Ed.). Jakarta: PT Bumi Timur Jaya.

Ricarhd, D. T. dkk. (2012). Physical Education, Obesity, and Academic Achievement: A 2-Year Longitudinal Investigation of Australian Elementary School Children. American Journal of Public Health., 102.

Rini Hildayani. (2016). Psikologi Perkembangan Anak. (Universitas Terbuka, Ed.). Tangerang.

Santrock, J. W. (2011). Perkembangan Anak. (Salemba Humanika., Ed.). Jakarta: PT Bumi Timur Jaya.

Sher, B. (2009). Early intervention games: fun, joyful ways to develop social and motor skills in children with Autism Spectrum or sensory processing disorders. John Wiley \& Sons.

Sugiyono. (2013). Metode Penelitian Kuantitatif, Kualitatif, dan R\&D. (Alfabeta, Ed.). Bandung.

Yasbiati, dan Nur, L. (2017). Strategi Pengembangan Fisik Motorik. (C. Universitas Suryakancana, Ed.). Tasikmaaya. 